\title{
Strategi Menghadapi Orang Munafik Menurut Alquran
}

\author{
Iril Admizal
}

Institut Agama Islam Negeri (IAIN) Curup

Iriladmizal7@gmail.com

DOI: http://dx.doi.org/10.29240/alquds.v2i1.391

Submitted: 2018-03-18 | Revised: 2018-05-26 | Accepted: 2018-06-05

\begin{abstract}
In the Qur'an, the word nifaq with its various forms that contain the meaning of hypocrisy, called as many as 37 times, contained the meaning of holding, taking part in talking about something that in the religious view, the confession of one person is different from the others. This nature, can create a variety of problems, personal and community. Therefore, this paper is aimed at exploring Qur'anic verses that relate to the existence of hypocrites, especially about the strategy of confronting them through thematic commentary methods. This study found that the strategy of confronting the hypocrites according to the Qur'an are, (1) strengthening the loyalty of fellow Muslims, (2) rejecting them as close friends, (3) rejecting them as leaders, (4) jihad, (5) building awareness, 6) reproduce prayer
\end{abstract}

Keywords: Strategy, Hypocrites, Tafsir Maudhu'i

\begin{abstract}
Abstrak: Dalam Alquran, kata nifâq dengan berbagai bentuknya yang mengandung makna kemunafikan, disebut sebanyak 37 kali, menandung arti mengadakan, mengambil bagian dalam membicarakan sesuatu yang dalam pandangan keagamaan, pengakuannya dari satu orang berbeda-beda dengan yang lainnya. Sifat seperti ini, bisa menciptakan berbagai persoalan dan permasalahan baik itu pribadi maupun masyarakat. Oleh karena itu, tulisan ini diarahkan pada upaya mengeksplorasi ayat-ayat Alquran yang berhubungan dengan eksistensi orang munafik, khususnya tentang strategi menghadapi mereka melalui metode tafsir tematik. Penelitian ini menemukan bahwa strategi menghadapi orang munafik menurut Alquran adalah, (1) memperkokoh loyalitas sesama muslim, (2) menolak mereka sebagai teman dekat, (3) menolak mereka sebagai pemimpin, (4) melakukan jihad, (5) membangun kewaspadaan, (6) memperbanyak doa.
\end{abstract}

Kata Kunci: Strategi, Orang Munafik, Tafsir Maudhu’i

\section{Pendahuluan}

Dinamika kehidupan manusia ditinjau dari sifat-sifat yang dimilikinya terus akan mengalami perkembangan sesuai dengan fenomena dan eksistensi subyek-subyek lain di dalam diri maupun di lingkungan sekitarnya yang turut 
mempengaruhi pembentukan karakternya dari potensi dasar yang telah dimilikinya sejak lahir. ${ }^{1}$ Sampai kemudian ada yang terakumulasi menjadi karakter khas atau kebiasaan yang selalu muncul setiap kali ia melakukan interaksi antar sesama.

Karakter diri seseorang dalam hal ini secara lahiriah dapat diketahui salah satunya yang paling umum dari sifat bicaranya. Yaitu dengan memperhatikan kesesuaian antara apa yang diucapkan dengan apa yang dilakukannya. Atau lebih mendalam lagi, apakah ada kesesuaian antara apa yang diucapkannya dengan apa yang ia yakini dalam hatinya. Kemudian dengan memperhatikan konsistensi dari sifat bicaranya tersebut bila dihadapkan pada situasi atau orang yang berbeda dengan pertama kali waktu ia mengucapkannya.

Dalam realita sehari-hari sering dijumpai ada orang yang begitu mudah mengucakan perkataan yang ia sendiri dalam hati mengingkarinya. Di tempat lain ia berkata setuju, tetapi di tempat lain pula ia berkata tidak begitu. Atau pada satu waktu ia berjanji, namun pada waktu yang lain ia mengingkarinya. Karakter seperti tersebut kerap kali dapat disaksikan dalam kehidupan bermasyarakat, berbangsa dan bernegara. Bahkan kemudian ada yang saling tuding satu dengan lainnya dengan memberi predikat sebagai orang munafik. ${ }^{2}$ Begitu mudahnya predikat tersebut dilabelkan pada seseorang, yang kemudian tidak jarang menimbulkan pertengkaran dan permusuhan.

Alquran menggambarkan sosok orang munafik sebagai orang yang memiliki kepribadian terpecah, bermuka dua, tidak adanya kesesuaian antara yang diperlihatkannya dengan apa yang sebenarnya di dalam batinnya. Karakter yang muncul pada dirinya sangat tergantung dan dipegaruhi oleh ambisi pribadi yang cendrung tidak sesuai dengna eksistensi dan kemampuan diri yang sesungguhnya. Kebohongan merupakan karakter dasarnya untuk menutupi segala keburukan dirinya dan kejahatan yang dilakukannya. Secara lahiriah dia selalu berusaha untuk memperlihatkan diri sebagai sosok terbaik yang sempurna

${ }^{1}$ Dalam al-Qur'an potensi dasar manusia itu disebut dengan fitrah yang disebutkan pada serah al-Rum/30:30. Dalam hal ini penafsiran kata fithrab pada ayat tersebut diterjemahkan dan didefinisikan oleh banyakpakar dengan makna yang bermacam-macam. Diantara arti-arti yang dimaksud adalah: thur (suci), Islâm (agama Islam), taubîd (mengakui keesaan Allah), Ikblâsh (murni), al-Gharizą (insting), Kecendrungan manusia untuk menerima dan berbuat kebenaran, potensi dasar untuk mengabdi kepada Allah dan fithrah juga berarti ketetapan atas manusia baik kebahagiaan maupun kesengsaraaan, dan sebagainya. Lihat Armai Arief, Pengantar Ilmu Dan Metodologi Pendidikan Islam (Jakarta: Ciputat Press, 2002), 7.

${ }^{2}$ Dalam Kamus Besar Babasa Indonesia, kata munafik diartikan: berpura-pura percaya atau setia dan sebagainya kepada agama dan sebagainya tetapi sebenarnya dalam hati tidak; atau suka (selalu) menyatakan sesuatu yang tidak sesuai dengan perbuatannya; atau bermuka dua. Lihat Tim Penyusun Kamus Pusat Pembinaan dan Pengembangan Bahasa Departemen Pendidikan dan Kebudayaan, Kamus Besar Babasa Indonesia, 2nd ed. (Jakarta: Balai Pustaka, 1995), 599. 
dalam pandangan orang lain, padahal di balik semua itu tersimpan niat buruk dan hati yang sakit. Intinya, orang munafik adalah orang yang keadaan lahirnya berlawanan dengan batinnya baik dari aspek perkataan maupun perbuatannya.

Alquran mengungkapkan kata nifâq dengan berbagai bentuknya yang mengandung makna kemunafikan, disebut sebanyak 37 kali. Melihat banyaknya ayat Alquran yang menjelaskan tentang kemunafikan maka secara garis besar sifat kemunafikan itu dapat dibagi mencari dua yaitu: pertama, nifâq besar; nifâq seperti ini sangat membahayakan bagi agama karena orang seperti ini mempunyai kebencian terhadap Islam dan dianggap sudah keluar dari Islam. Kedua, nifâq kecil; jenis nifâq ini tidak sampai keluar dari Islam, tapi sangat berbahaya bagi pergaulan sehari-hari karena yang termasuk dalam perbuatan ini adalah dusta dalam perkataan, tidak menepati janji, mengkhianati amanah, berlaku curang ketika bertengkar dengan jalan keluar dari aturan akhlak yang luhur, dan menipu.

Keberadaan orang munafik baik itu dalam bentuk nifâq besar maupun nifâq kecil sangat membahayakan bagi kehidupan. Mereka senantiasa terus ada pada setiap tempat dan zaman sepanjang kehidupan umat manusia. Bahaya yang ditimbulkan olehnya meliputi seluruh aspek kehidupan, baik secara individu maupun masyarakat, menyangkut persoalan keagamaan (iman dan peribadatan) maupun persoalan kehidupan berbangsa dan bernegara. Kemunafikan merupakan virus yang dapat menyebar dan merusak sendi-sendi kehidupan.

Penelitian ini diarahkan pada upaya mengeksplorasi ayat-ayat Alquran yang berhubungan dengan eksistensi orang munafik, khususnya tentang strategi menghadapi mereka melalui pendekatan tafsir tematik. Ada penelitian yang membahas tentang tema yang hampir sama, yang berjudul Rekonstruksi Penafsiran Ayat-Ayat Amtsal Tentang Kaum Munafik: Studi Pemikiran Mubammad 'Abdub dalam Tafsir al-Manar ditulis oleh Nunung Lasmana Pascasarjana Institut Ilmu Alquran (IIQ) Jakarta. Penelitian ini hanya memaparkan pendapat Muhammad 'Abduh tentang orang munafik dan penelitian ini tidak membahas tentang cara menghadapinya. Oleh karena itu, penelitian yang penulis lakukan ini bisa melengkapi penelitian yang sudah ada. Penulis lebih mengarahkan kepada cara menghadapi orang-orang munafik. Dalam memaparkan ayat-ayat Alquran, penulis hanya mengambil ayat-ayat yang dipandang bisa mewakili dari ayat yang membicarakan tetang orang munafik.

\section{Pengertian Munafik}

Secara etimologi, kata munafik dalam bahasa Arab diambil dari akar kata nafiqa (نق) yang berarti lobang tikus. Dalam hal ini, antara lobang tikus dengan kemunafikan memang ada kesejajaran sifat. Bagian atas (luar) dari liang tikus 
tertutup dengan tanah, sedangkan bagian bawahnya berlobang. Demikian pula dengan kemunafikan yang bagian luar adalah Islam tetapi bagian dalamnya merupakan keingkaran serta penipuan. ${ }^{3}$ Atau karena biasanya tikus selalu menampakkan jalan masuknya ke lobang, namun tidak menampakkan jalan keluarnya. Jadi, arti dasarnya adalah menampakkan sesuatu dan menyembunyikan lawannya. ${ }^{4}$

Kata munafik juga berasal dari kata nâfaqa-Nifâqan (نفافق - ناقا)yang menandung arti mengadakan, mengambil bagian dalam membicarakan sesuatu yang dalam pandangan keagamaan, pengakuannya dari satu orang berbeda-beda dengan yang lainnya. ${ }^{5}$ Al-Râghib al-Ashfahânî mengartikan nifâq dengan masuk ke dalam syara' (agama) dari satu pintu dan keluar dari padanya melalui pintu lain. ${ }^{6} \mathrm{Hal}$ ini didasarkan pada Alquran Surat al-Taubah/9:67 yang menyatakan bahwa orang-orang munafik itu adalah orang yang fasiq. Oleh al-Jurjânî kata niffâq diartikan menampakkan keimanan melalui perkataan dan menyembunykna kekafiran dalam hati. ${ }^{7}$

Dalam Alquran kata nifâq dengan berbagai bentuknya yang mengandung makna kemunafikan, disebut sebanyak 37 kali. Bila diklasifikasikan, ayat-ayat Alquran yang membahas tema kemunafikan, kebanyakan diturunkan di madinah (madaniyyah). ${ }^{8}$ Ini disebabkan karena fenomena kemunafikan kelihatan sangat pesat kemunculan dan perkembangannya pada periode Madinah.

Secara terminologi, munafik adalah orang yang menampakkan sesuatu yang sejalan dengan kebenaran di depan orang banyak, padahal kondisi batin atau perbuatannya yang sebenarnya tidak demikian. Kepercayaan atau perbuatannya itu disebut nifâq. ${ }^{9}$

${ }^{3}$ Ahmad 'Izz al-Din al-Bayanuni, Al-Kufr Wa Al-Mukaffirat (Halb: Maktabah al-Huda, 1979), 47.

${ }^{4}$ Ibrahin ibn Muhammad bin Abdullah Al-Buraikhan, Pengantar Studi Aqidah Islam, trans. Muhammad Anis Matta (Jakarta: Robbani Press, 1998), 200.

${ }^{5}$ Abdullah Abbas Al-Nadur, Qamus Alfazh Al-Qur'an (Beirut: Dar Al-Fikr, 1986), 524.

${ }^{6}$ Ar-Raghib Al-Ashfahaniy, Mu'jam Mufradat Alfazh Al-Qur'an (Beirut: Dar Al-kutub Al-Ilmiyah, 2008), 524.

${ }^{7}$ Ali ibn Muhammad ibn 'Ali al-Husaini al-Jurjani, Al-Ta'rifat (Beirut: Dar al-Kutub alIlmiyyah, 2003), 241.

${ }^{8}$ Muhammad Fu'ad Abd al-Baqi, Al-Mu'jam Al-Mufahras Li Alfą̧h Al-Qur'an Al-Karim (Beirut: Dar Al-Fikr, 1417), 886-87.

${ }^{9}$ Al-Buraikhan, Pengantar Studi Aqidah Islam, 201. 
Dalam istilah Alquran, menurut al-Thabâthabầ̂, nifâq adalah menampakkan iman dan menyembunyikan kekafiran. ${ }^{10}$ Hal ini didasarkan pada Qs. Al-Mầidah/5:41 yang berbunyi:

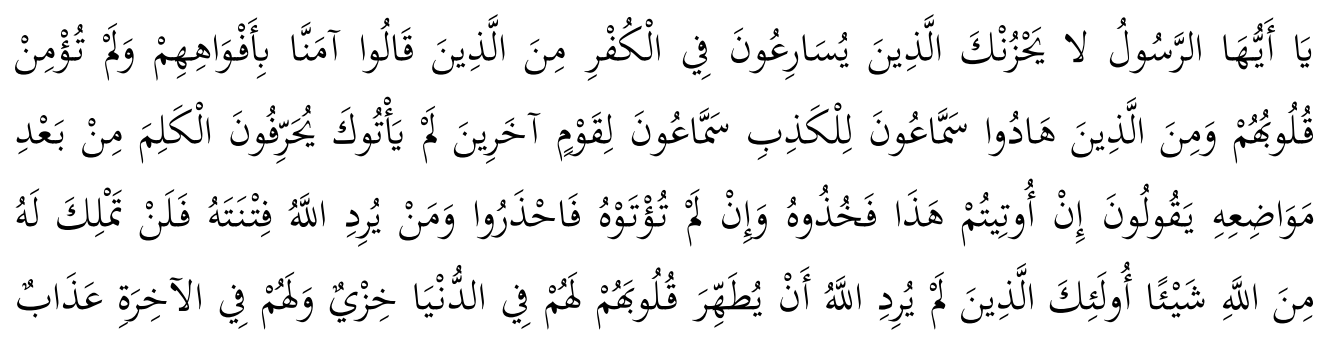

Hai Rasul, janganlah kamu disedihkan oleh orang-orang yang bersegera (memperlihatkan) kekafirannya, yaitu orang-orang yang mengatakan dengan mulut mereka: "Kami telah beriman", padahal hati mereka belum beriman; dan (juga) dari orang-orang Yahudi yang amat suka mendengar (beritaberita) bohong dan amat suka mendengar perkataan-perkataan orang lain yang belum pernah datang kepadamu; mereka merobah perkataan-perkataan (Taurat) dari tempat-tempatnya. Mereka mengatakan: "Jika diberikan ini (yang sudah di robah-robah oleh mereka) kepada kamu, maka terimalah, dan jika kamu diberi yang bukan ini, maka hati-hatilah". Barangsiapa yang Allah menghendaki kesesatannya, maka sekali-kali kamu tidak akan mampu menolak sesuatupun (yang datang) daripada Allah. Mereka itu adalah orang-orang yang Allah tidak hendak mensucikan hati mereka. Mereka memperoleh kehinaan di dunia dan di akhirat. Mereka juga memperoleh siksaan yang besar.

Jadi orang-orang munafik itu melalui lidahnya mengaku beriman, tunduk dan patuh kepada Allah, padahal sesungguhnya tidaklah demikian, bahkan merekalah penentang yang sangat gigih yang di dalam hati mereka dikotori oleh kekafiran.Dengan demikian mereka sebenarnya dapat dikelompokkan dalam golongan orang-orang kafir.

Kemunafikan dimasukkan dalam kategori kekafiran karena pada hakikatnya perilaku nifâq adalah kekafiran yang terselubung. Orang-orang munafik, pada dasarnya, adalah mereka yang ingkar kepada Allah, kepada Rasul-

${ }^{10}$ Muhammad Husayn Thabathaba'i, al-Mizan fi Tafsir al-Quran, 19 (Tegeran: Mu’assasat Dar al-Kutub al-Islamiyyah, 1396), 323. 
Nya dan ajaran-ajaran yang dibawa rasul itu, kendatipun secara lahir mereka memakai baju mukmin. ${ }^{11}$

Dari pembahasan di atas, perilaku nîfâq dapat dikelompokkan menjadi dua kategori. Yaitu, nîfâq yang berhubungan dengan keimanan (aqîdah) dan nîfâq yang berhubungan dengan amal perbuatan ('amali). ${ }^{12}$

Nifâq aqîdah adalah penyebunyian kekafiran dalam hati dan menampakkan keimanan dalam lisan dan perbuatan. Orang-orang yang berprilaku demikian biasanya hanya akan dan sengaja menampakkan keimanannya melalui pernyataan lisan dan perbuatan bila ia berhadapan atau berada di tengah-tengah orang beriman. Dalam hal ini, keyakinannya tentang hakekat Islam sesungguhnya sangat bertentangan dengan pernyataan keimanan dan keislamannya tersebut. ${ }^{13}$

Sedangkan nifâq 'amali adalah menampakkan perbuatan yang berbeda dengan apa yang diperintahkan syari'at Islam. Orang-orang yang berperilaku demikian memiliki akhlak orang-orang munafik dalam memberikan loyalitas kepada orang-orang kafir, berkasih sayang kepada mereka, mendukung perjuangan mereka, menyalahi janji, membiasakan berdusta, atau berkhianat, curang dan sebagainya. Dalam kehidupan sehari-hari orang seperti ini akan berusaha kelihatan bersikap manis dan lembut untuk mendapat simpatik dan kepercayaan dari orang di sekitarnya, padahal di dalam hatinya berkecamuk kebencian dan tipu daya. ${ }^{14}$

Dari beberapa pengertian tentang nifâq dan orang munafik yang diutarakan di atas dapat disimpulkan bahwa kemunafikan tidaklah semata-mata berhubungan dengan persoalan keimanan yang menjurus pada masalah kebohongan dan pengkhianatan kepada Allah dan Rasul-Nya, tetapi munafik juga meliputi segala persoalan yang berhubungan dengan amal perbuatan manusia dalam berinteraksi dengan sesamanya, yakni dengan berperilaku ganda atau bermuka dua dalam bersikap di hadapan orang, kata lisan dan perbuatannya sangat bertentangan dengan ketentuan dan tuntutan syara' sebagaimana yang telah diyakini kebenarannya.

${ }^{11}$ Harifuddin Cawidu, Konsep Kufr Dalam Al Qur'an (Jakarta: Bulan Bintang, 1991), 124.

$1212 \mathrm{Ibn}$ al-Qayyim al-Jauziyyah menggunakan istilah lain untuk pembagian nifâq ini, yaitu nîfâq Akbar (nifaq besar) dan nifâq Asghar (nifaq kecil). Lihat Ibn al-Qayyim al-Jauziyyah, Madarijus Salikin: Pendakian Menuju Ilabi, trans. Kathur Suhardi (Jakarta: Pustaka al-Kautsar, 1998), 68; Sedangkan Sa’id Hawwa menyebutkan nifâq nažhari (Konsepsional) dan niffâq'Amali. Lihat Sa'id Hawwa, Mensucikan Jiwa; Konsep Tazkiyatun Nafs Terpadu, trans. Aunur Rafiq Shaleh (Jakarta: Rabbani Press, 1998), 182.

13 al-Jauziyyah, Madarijus Salikin, 68; Hawwa, Mensucikan Jiwa, 182.

${ }^{14}$ al-Jauziyyah, Madarijus Salikin, 68; Hawwa, Mensucikan Jiwa, 182. 


\section{Hal-Hal Yang Harus Dilakukan Untuk Menghadapi Orang Munafik}

Pada pergaulan sehari-hari kita akan menemukan orang-orang munafik untuk itu, Alquran memberikan solusi dalam menghadapi orang-orang munafik:

1. Memperkokoh loyalitas sesama Muslim

Untuk menghadapi orang munafik yang melakukan konspirasikonsporasi buruk dan perilaku-perilaku tercela yang membahayakan orang-orang mukmin, Allah Swt mengajarkan kepada orang-orang mukmin agar memperkokoh loyalitas sesama mukmin dalam bingkai persatuan Islam. Ini merupakan salah satu tarbiyyah Ilâbi yang terkandung dalam Alquran sebagai mana diungkapkan pada surah al-Nisâ'/4: 88 sebagai berikut:

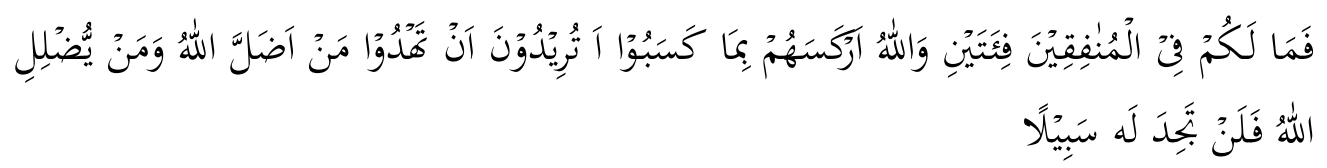

Maka mengapa kamu (terpecah) menjadi dua golongan dalam (menghadapi) orang-orang munafik, padahal Allah telah membalikkan mereka kepada kekafiran, disebabkan usaha mereka sendiri? Apakah kamu bermaksud memberi petunjuk kepada orang-orang yang telah disesatkan Allah? Bagisiapa yang disesatkan Allah, sekali-kali kamu tidak mendapatkan jalan (untuk memberi petunjuk) kepadanya.

Sebab turunnya ayat ini sebagaimana diriwayatkan oleh Bukhâri dan Muslim yang bersumber dari Zaid ibn Tsâbit, bahwa ketika Rasulullah saw, berangkat untuk perang Uhud, beberapa orang pasukan yang tadinya ikut bersama beliau kembali pulang tidak jadi ikut berperang,maka terjadilah perbedaan pendapat di kalangan para sahabat Rasulullah saw saat itu. Dalam hal ini ada dua pendapat yang muncul, yang pertama mengatakan akan membunuh mereka yang melakukan disersi (lari dari perang) itu, sementara yang lainnya mengatakan tidak boleh membunuhnya. Maka Allah Swt. menurunkan ayat ini. ${ }^{15}$

Ibn Katsîr mengomentari ayat ini, bahwa Allah Swt. melalui firman-Nya ini mengingkari perselisihan orang-orang mukmin yang berbeda sikap dan pandangan dalam menghadapi kaum munafik. ${ }^{16}$ Itu berarti sebaliknya, bahwa

${ }^{15}$ Abi al-Hasan 'Ali ibn Ahmad al-Wahidi al-Naisaburi, Asbab Al-Nu₹ul (Beirut: Dar Al-Fikr, 1994), 93.

${ }^{16}$ Imaduddin Abi al-Fida Isma'il ibn Katsir, Tafsir Al-Qur'an Al-Az̧bim, 2 (Kairo: Maktabah al-Shafa, 2004), 224. 
Allah Swt, memerintahkan orang-orang mukmin untuk merapatkan barisan, bersatu dalam visi dan misi dalam menghadapi orang-orang munafik.

Muhammad 'Alî Al-Shâbûni menegaskan bahwa dengan kata lain, ayat ini seakan bertanya kepada orang-orang mukmin dengan penuh keheranan, mengapa mereka terbagi menjadi dua golongan dalam menghadapi orang-orang munafik? Yang satu berkata, "Kita harus memerangi mereka karena mereka adalah musuh."Sementara yang satunya lagi berkata, "Kita tidak boleh memerangi mereka karena mereka saudara kita dalam agama." Padahal pada ayat sebelumnya juga ayat-ayat sesudahnya dalam surat al-Nisâ ini Allah Swt, telah mengungkap sikap orang-orang munafik yang hina dan cara-cara yang licik, meletakkan batas yang jelas antara orang yang beriman dan orang munafik yang sesat, untuk memperingatkan orang-orang mukmin, agar tidak saling berselisih di antara mereka sendiri tentang keberadaan orang-orang munafik itu. Meskipun mereka menampakkan keislamannya, namun pada hakikatnya mereka adalah orang-orang kafir dan keji, yang selalu menginginkan bencana bagi orang-orang mukmin. ${ }^{17}$

Melihat penjelasan dari ayat ini, tidak ada gunanya membela orang-orang munafik yang sudah sampai pada tingkat nifak besar itu dengan bersikap lembek atas mereka, mengharapkan mereka agar mendapat hidayah Allah Swt, hingga mereka berbalik untuk berpihak dan mendukung perjuangan orang-orang mukmin. Karena Allah Swt sendiri telah menyatakan kekufuran mereka dan menegaskan bahwa sekali-kali tidak ada seorangpun yang dapat memberi jalan untuk mereka guna memperoleh petunjuk, bahkan Rasulullah Muhammad saw pun tidak. Mereka telah tersesat akibat perbuatan mereka sendiri yang berkeinginan dan berusaha untuk sesat.

Oleh karenanya orang-orang mukmin harus mengambil sikap tegas terhadap mereka, membangun visi dan misi yang sama dalam menghadapi berbagai konspirasi dan usaha mereka yang senantiasa dan secara terus menerus berusaha menghancurkan Islam dan umat Islam. Disinilah persatuan di kalangan sesama mukmin harus dinyatakan dalam realitas gerakan ('amali), bukan sematamata dalam teori ('ilmi) belaka. Allah berfirman dalam Surat Alî 'Imran: 103

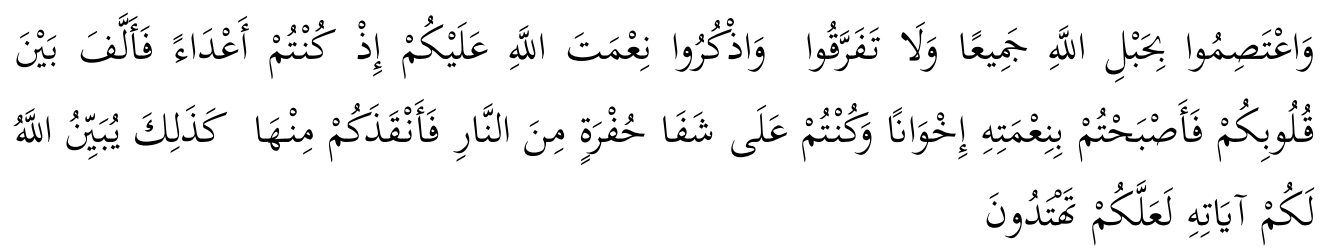

${ }_{17}$ Muhammad 'Ali Al-Shabuni, Cahaya Al-Qur'an; Tafsir Tematik Surat Al-Baqarah-AlAn'am,1, trans. Kathur Sukardi (Jakarta: Pustaka al-Kautsar, 2000), 212. 
Dan berpeganglah kamu semuanya kepada tali (agama) Allah, janganlah kamu bercerai berai. Ingatlah akan nikmat Allah kepadamu ketika kamu dahulu (masa Jahiliyah) bermusuh-musuhan, Allah mempersatukan hatimu, lalu menjadilah kamu, karena nikmat Allah, orang-orang yang bersaudara; dan kamu telah berada di tepi jurang neraka, lalu Allah menyelamatkan kamu dari padanya. Demikianlah Allah menerangkan ayat-ayat-Nya kepadamu, agar kamu mendapat petunjuk.

Ayat ini memperingatkan kaum mukmin akan nikamat Allah yang besar yang telah merobah situasi permusuhan dengan mendatangkan cinta dan persahabatan di antara mereka sebagai ganti dari rasa saling benci dan permusuhan, akbitnya, yang tadinya menjadi musuh kemudian berubah menjadi sahabat/saudara.

Pada ayat ini, dapat difahami juga bahwa persatuan yang harus ditegakan oleh kaum muslimin adalah persatuan yang didasari dengan ketaatan dalam mengamalkan ajaran Alquran. Itu berarti membawa konsekwensi bahwa apapun yang dilakukan oleh orang-orang muslim haruslah sesuai dengan perintah dan ajaran Alquran.

Persatuan seperti ini akan terwujud apabila orang-orang mukmin memiliki loyalitas yang sama di antara mereka. Tidak ada penghianatan dan kecurangan sebagaimana yang telah diperlihatkan oleh orang-orang munafik dalam menghancurkan kaum mukmin pada masa Rasulullah saw. Terwujudnya persatuan Islam bukan suatu keniscayaan yang mustahil, karena agama Islam menurutnya adalah menyatukan bukan memecah belah.

\section{Menolak Mereka Sebagai Teman Dekat}

Setelah menyeru orang-orang mukmin untuk bersatu dan meningkatkan loyalitas di antara mereka dalam menghadapi orang-orang munafik, Alquran juga memperingatkan mereka untuk mengambil sikap penolakan terhadap orangorang munafik dalam menjadikan mereka sebagai teman karib dan penolong. Strategi seperti ini disebut dalam surat al-Nisâ'/4:89. Allah Swt berfirman:

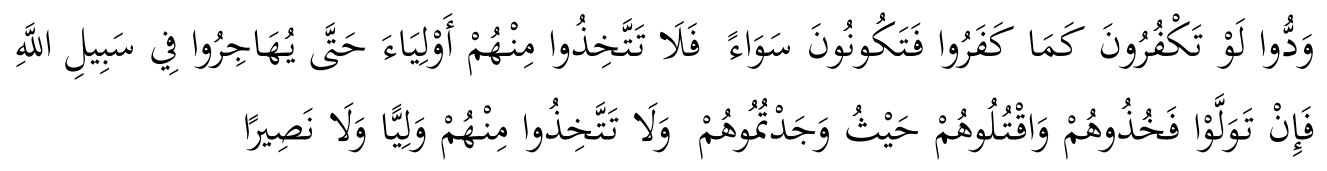

Mereka ingin supaya kamu menjadi kafir sebagaimana mereka telah menjadi kafir, lalu kamu menjadi sama (dengan mereka). Maka janganlah kamu jadikan di antara mereka penolong-penolong $(\mathrm{mu})$, hingga mereka berhijrah pada jalan Allah. Maka jika mereka berpaling, tawan dan Bunuhlah mereka 


\section{di mana saja kamu menemuinya, dan janganlah kamu ambil seorangpun di antara mereka menjadi pelindung, dan jangan (pula) menjadi penolong.}

Pada ayat ini, Allah Swt kembali membimbing hamba-hamba-Nya yang beriman dengan pengajaran yang sangat logis untuk difahami, dimana sebaelum Dia memerintahkan orang-orang mukmin dengan larangan-Nya mengambil orang-orang munafik sebagai teman dekat dan penolong sebagai salah satu sikap yang hurs diambil oleh orang-orang mukmin terhadap orang-orang munafik, Dia terlebih dahulu menjelaskan kembali keburukan kepribadian orang-orang munafik sebagai tambahan deretan panjang catatan hitam perilaku mereka yang tidak hanya berbuat kekufuran atas diri mereka sendiri, tetapi juga berusaha untuk menjadikan orang-orang mukmin berpaling dari keimanannya menuju kekufuran sebagaiman mereka telah kufur.

Degan kata lain, mereka (orang-orang munafik) adalah "virus" yang membinasakan dan "wabah" yang menggerogoti tubuh masyarakat Islam dalam membina, menjaga dan mempertahankan keimanannya. Sehingga tidak ada alasan bagi orang-orang Islam yang beriman untuk tidak menolak mereka menjadi teman dekat. Dan adalah sikap yang sangat tidak pantas kalau kemudian orang-orang mukmin meminta pertolongan kepada mereka.

Muhammad 'Alî Al-Shâbûnî menafsirkan "Maka janganlah kamu jadikan di antara mereka penolong-penolong ( $\mathrm{mu}$ ), hingga mereka berhijrah pada jalan Allah" yaitu jangan menjadikan satupun di antara mereka sebagai penolong dan teman hingga mereka beriman dan membuktikan keimanannya dengan hijrah dan jihad di jalan Allah. ${ }^{18}$ Dalam konteks kekinian kata hijrah dalam ayat ini difahami sebagai sikap dan perilaku yang menujukkan kemantapan iman dan keseriusan dalam melaksanakan ajaran Islam. ${ }^{19}$ Dengan kata lain apabila mereka (orang-orang munafik) itu telah bertobat dari kemunafikannya dengan buktibukti yang nyata bahwa mereka telah berubah maka larangan untuk menjadikan mereka sebagai teman tidak lagi berlaku.

Lebih lanjut, M. Quraish Shihab menjelaskan bahwa ayat ini bukan berarti melarang orang-orang mukmin menjalin hubungan dengan orang-orang munafik.Ia hanya melarang menjalin hubungan akrab. Itupun hanya dengan

18 ibn Katsir, Tafsir Al-Qur'an Al-Az̧̧im, 2, 225.

${ }^{19}$ Pemahaman ini diambil karena kewajiban hijrah yang dimaksud pada ayat tersebut adalah sebelum kata mekah dikuasai oleh kaum muslimin. Ketika itu perjuangan Islam sangat membutuhkan kehadiran semua umatnya dalam satu lokasi dan karena itu pula ketika itu Nabi saw, bersabda: "Saya berlepas diri setiap muslim yang berdomisili bersama orang-orang musyrik" Disisi lain, konteks ini perlu juga diingatkan bahwa Nabi saw dalam sabdanya menyatakan: "Tidak ada lagi hijrah setelah fath (pembebasan kota Mekah dari kekuasaan kaum musyrik) tetapi yang ada (sesudah itu) adalah jihad dan niat yang tulus (untuk menegakkan ajaran Islam)." Lihat M. Quraish Shihab, Tafsir Al-Misbah, 2 (Jakarta: Lentera Hati, 2002), 512. 
orang-orang yang telah terang-terangan secara nyata memusuhi Islam, sekalipun mereka mengaku sebagai orang-orang Islam. ${ }^{20}$

Larangan untuk menjadikan mereka sebagai teman dekat dengan meminta pertolongan kepada mereka dalam ayat ini disebutkan oleh Allah secara berulang. Yaitu ketika Allah Swt terlebih dahulu mengungkap sisi buruk perilaku mereka terhadap orang-orang mukmin dan mengulangi larangan itu lagi setelah memberi penegasan akan pembangkangan mereka yang harus disikapi dengan cara menawarkan dan membunuh mereka. Ini berarti bahwa larangan untuk menolak orang-orang munafik sebagai teman dekat dan penolong merupakan larangan yang sangat keras, sehingga Allah harus mengulang dua kali. Pengulangan itu sekaligus menunjukkan bahwa arti dari larangan itu memiliki nilai yang sangat penting dalam menjaga dan menyelamatkan kaum muslimin dari akibat negatif perilaku orang-orang munafik yang tidak henti-hentinya menimbulkan kemudaratan bagi kaum muslimin.

Dalam surat Ăli 'Imrâan: 118, Allah juga memperingatkan tetang bahaya orang munafik dijadikan sahabat:

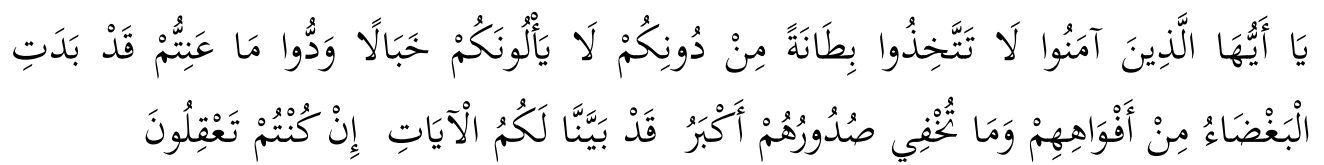

Hai orang-orang yang beriman, janganlah kamu ambil menjadi teman kepercayaanmu orang-orang yang, di luar kalanganmu (karena) mereka tidak henti-hentinya (menimbulkan) kemudharatan bagimu. mereka menyukai apa yang menyusahkan kamu. Telah nyata kebencian dari mulut mereka, dan apa yang disembunyikan oleh hati mereka adalah lebih besar lagi. sungguh Telah kami terangkan kepadamu ayat-ayat (Kami), jika kamu memahaminya.

Beberapa ahli tafsir, seperti Ibn 'Abbâs, Mujâhid dan Qatadah menyatakan bahwa yang dimaksud dengan orang-orang yang di luar kalanganmu pada ayat tersebut adalah orang munafik, meskipun juga bisa berlaku untuk setiap non muslim lainnya. ${ }^{21}$

Ayat di atas mengandung larangan terhadap orang-orang mukmin agar tidak menjadikan orang-orang munafik sebagai teman dekat karena mereka akan membongkar rahasia-rahasia dan apa yang disembunyikan oleh kaum mukmin kepada pihak musuh. Orang-orang munafik, dengan upaya dan

20 Ibid.

21 Abu Ja'far bin Jarir al-Thabari, Jami' Al-Bayan Fi Ta'mîl Al-Qur'an, 3 (Beirut: Dar alKutub al-Ilmiyyah, 1999), 407. 
kemampuan yang mereka miliki, senantiasa berusaha untuk merugikan dan memudharatkan orang-orang mukmin dengan berbagai strategi, termasuk menggunakan cara-cara muslihat serta tipu daya yang dapat mereka terapkan. Mereka menyenangi sesuatu yang dapat menyusahkan, menyengsarakan, dan memberatkan orang-orang mukmin. ${ }^{22}$

Namun demikian, penolakan terhadap orang-orang munafik sebagai teman dekat bukan berarti menjauhi mereka secara total. Pergaulan dan kerjasama untuk tolong-menolong atau bergontong royong dengan mereka tetap dapat dilakukan dalam kehidupan masyarakat, selama umat Islam tetap tunduk pada kriteria-kriteria Islam dalam menentukan bentuk-bentuk kerjasama. Sebab tidak semua kegiatan dan aktivitas di dalam masyarakat dapat dilakukan kerjasama antar kaum muslimin dengan golongan kafir (munafik).

3. Menolak Mereka Sebagai Pemimpin

Dalam kehidupan politik, orang-orang mukmin dilarang dan harus menolak untuk memilih dan menjadikan orang-orang munafik sebagai pemimpin. Logika ini seharusnya telah ditangkap baik dan difahami oleh orangorang mukmin setelah sebelumnya mengetahui tentang larangan menjadikan orang-orang munafik sebagai teman dekat dan kemudharatan yang ditimbulkan sebagaimana telah diuraikan sebelumnya.

Alquran dengan tegas menyampaikan larangan tentang ini. Sebagaimana firman Allah dalam surat al-Mâidah/5:57:

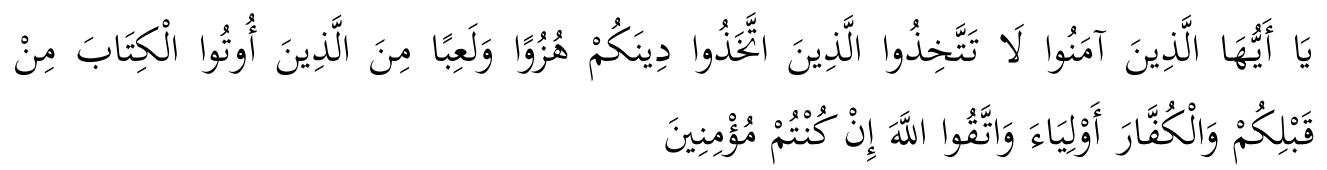

Hai orang-orang yang beriman, janganlah kamu mengambil jadi pemimpinmu, orang-orang yang membuat agamamu jadi buah ejekan dan permainan, (yaitu) di antara orang-orang yang Telah diberi Kitab sebelummu, dan orang-orang yang kafir (orang-orang musyrik). Bertakwalah kepada Allah jika kamu betul-betul orang-orang yang beriman.

Beberapa ahli tafsir menyatakan bahwa yang dimaksud dengan orangorang yang sebelum kaum yang telah diberi kitab adalah orang-orang Yahudi dan Nasrani. Dan yang dimaksud dengan orang-orang kafir adalah orang-orang musyrik dan orang-orang munafik. ${ }^{23}$ Berdasarkan pada riwayat dari Ibn 'Abbâs, ayat ini turun berkaitan dengan sikap orang-orang Yahudi dan orang-orang

\footnotetext{
22 ibn Katsir, Tafsir Al-Qur'an Al-Az̧bim, 2, 63.

${ }_{23}$ Abu Muhammad bin Ahmad al Anshari al Qurthubi, Al Jami' Li Abkam Al-Qur'an, 6 (Beirut: Dar al Kutub al Ilmiyah, 1993), 195.
} 
musyrik yang mentertawakan orang-orang muslim sewaktu mereka sujud dalam shalat. $^{24}$

Dimasukkannya orang-orang kafir ke dalam golongan orang-orang kafir karena pada dasarnya karakter dan sikap mereka dalam memusuhi orang-orang mukmin adalah sama. Pada ayat di atas, kesamaan orang-orang kafir dengan orang-orang munafik terlihat jelas dari sikap mereka yang merupakan pernyataan mereka sendiri yang suka mengejek dan mengolok-ngolok orang-orang mukmin.Atas dasar itulah beberapa mufasir berpendapat bahwa orang-orang munafik termasuk dalam kelompok orang-orang kafir yang disebut dalam ayat tersebut. ${ }^{25}$

Orang munafik yang dimaksud pada ayat di atas adalah orang munafik yang perilakunya telah sampai pada tingkat nifäq besar. Orang munafik pada tingkat ini sangat ditegaskan sangat oleh Allah agar tidak dipilih sebagai pemimpin. Adapun orang munafik pada tingkat nifâq kecil, bukan serta merta boleh dipilih untuk menjadi pemimpin. Hal ini perlu menjadi perhatian bagi kaum mukmin karena perilaku nifâq kecil pun pada diri seseorang pemimpin dapat membahayakan kehidupan masyarakat dan bernegara. Sehingga orang mukmin perlu berlaku cermat dalam hal ini, karena kepemimpinan sangat menentukan nasib kehidupan dalam bermasyarakat dan bernegara.

Ayat ini merupakan pemberitahuan kepada orang-orang mukmin agar tidak berwali kepada musuh-musuh Islam yang menjadi syari'at Islam yang suci, yang mengandung hikmah dan mencangkup seluruh kebaikan dunia dan akhirat sebagai bahan ejekan. Dimana pikiran mereka (musuh-musuh Islam) yang kacau memandangnya sebagai suatu jenis permainan. ${ }^{26}$

Dalam surat al-Nisâ':144 Allah juga menjelaskan lebih mungutamakan orang mukmin dari pada orang munafik dalam hal wili (penolong)

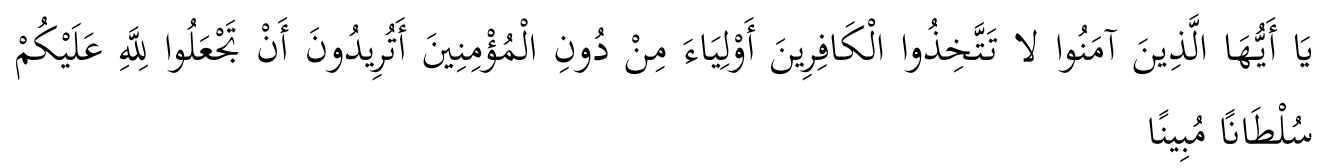

${ }^{24}$ Ibid.

25 Pendapat mereka ini berdasarkan pada dalil al-Qur'an surat al-Baqarah/2:14. Kesamaan kareakteristik mereka juga terlihat dari sifat-sifat mereka sebagaimana yang telah diuraikan pada pembahasan terdahulu.

${ }^{26}$ Imaduddin Abi al-Fida Isma'il ibn Katsir, Tafsir Al-Qur'an Al-Az̧bim, 3 (Kairo: Maktabah al-Shafa, 2004), 85. 
Hai orang-orang yang beriman, janganlah kamu mengambil orang-orang kafir menjadi wali dengan meninggalkan orang-orang mukmin. Inginkah kamu mengadakan alasan yang nyata bagi Allah (untuk menyiksamu)?

Keberdaan orang munafik yang oportunis itu akan menempatkan susatu negera berada dalam keadaan bahaya. Sebab mereka pandap berpura-pura untuk mencintai dan membela rakyat, kemudian dalam kondisi tertentu mereka tidak segan-segan untuk berkhianat dan membocorkan rahasia negara untuk kepentingan musuh.

Dari uraian di atas, semakin jelas bahwa orang-orang mukmin harus memiliki sikap penolakan terhadap kepemimpinan orang-orang munafik. Ini merupakan salah satu strategi Alquran dalam menghadapi orang-orang munafik untuk mencegah kehancuran kehidupan bermasyarakat bernegara akibat kemudharatan yang mereka lakukan.

Namun demikian, bertoleransi dan kasih sayang terhadap mereka itu harus, tetapi hal ini tidak boleh membuat identitas dan afiliasi orang-orang muslim pada agamanya luntur. Disini perlu diperhatikan bahwa ada perbedaan antara penghormatan, antara kerjasama yang positif, kasih sayang, dan toleransi dengan larut dalam identitas orang lain dan kehilangan identitas diri sendiri ${ }^{27}$ hal ini bahkan harus menjadi ciri khas yang terus hidup pada sisi kepribadian mukmin dalam hubungan interaksinya dengan nonmukmin, selain sebagai manhaj dakwah Islamiyah yang harus diterapkan dalam gerakannya. ${ }^{28}$

Berdasarkan itu pergaulan antara orang-orang mukmin dan orang-orang munafik,harus menepatkan orang-orang mukmin sebagai pihak yang lebih aktif untuk mempegaruhi mereka, membawanya pada kebaikan-kebaikan. Bukan sebaliknya, orang-orang munafik yang lebih berperan menjalankan misinya. Untuk itu cara terbaik yang sangat efektif untuk mendukungnya adalah menjadikan orang mukmin sebagai pemimpin dan menolak orang-orang munafik untuk menduduki posisi itu.

4. Melakukan Jihad

${ }^{27}$ Amru Khalid, Pesona Al-Qur'an Dalam Matarantai Surah Dan Ayat, trans. Ahmad Fadhil (Jakarta: Sahara Publishers, 2005), 112.

${ }^{28}$ Dakwah Islamiah itu diawali dengan amar ma'ruf dan naby munkar, yang tidak ada penafsiran logisnya kecuali bermakna mengesakan Allah secara sempurna, yakni mengesakan pada zat penafsiran logisnya kecuali bermakna mengesakan Allah secara sempurna, yakni megesakan pada zat sifat-Nya. Bahwa Dialah Sang Maha Pencipta segala sesuatu, dialah yang patut disembah, sedangkan mengabdi kepada selain-Nya merupakan kezaliman yang amat jauh, dan merupakan hawa nafsu serta angan-angan yang menghukumi rasio. Lihat Abu Zahrah, Dakwah Islamiyah, trans. Ahmad Subandi and Ahmad Sumpeno (Bandung: PT. Remaja Rosdakarya, 1994), 32. 
Kata jihad diambil dari bahasa Arab yang berasal dari akar kata jahada (ج) yang artinya kepayahan atau kesulitan. Atau dari kata jubd (ج) yang artinya kesungguhan dan kekuatan. ${ }^{29}$

Jihad yang berasal dari kata juhd (ج) dalam Alquran juga berarti kemampuan. ${ }^{30}$ Ini berarti menuntut mujâhid (orang yang melakukan jihad) mengeluarkan segala daya dan kemampuannya demi mencapai tujuan. Karena itu jihad adalah pengorbanan, dan dengan demikian mujâhid tidak menuntut atau mengambil, tetapi memberi semua yang dimilikinya.Ketika memberi, dia tidak berhenti sebelum tujuannya tercapai atau yang dimilikinya habis. ${ }^{31}$

Adapun menurut istilah, Al-Râghib al-Ashfahânî menyatakan bahwa jihad adalah mengerahkan segenap tenaga untuk mengalahkan musuh.Dalam hal ini jihad terbagi tiga macam, yakni jihad menghadapi musuh yang nyata, jihad menghadapi setan, dan jihad menghadapi hawa nafsu. Dan jihad ini dilakukan dengan tangan dan lisan. ${ }^{32}$

Al-Jurjânî mendefinisikan jihad adalah menyeru kepada agama yang haq (benar). ${ }^{33}$ Sasaran pokok jihad adalah menyeru manusia kepada jalan Islam, yaitu agar manusia mengabdi kepada Allah semata dan mengeluarkan mereka dari sistem pengabdian kepada sesama manusia menuju pengabdian kepada Rabbul Tbâd (Rabb yang pantas diabdi), serta menyingkirkan para penentang hukum Allah (thawaghut) di muka bumi dan menghilangkan dari dunia ini segala bentuk tindak kerusakan. ${ }^{34}$

Ini merupakan sasaran jihad Islam yang terbesar, yaitu mengembalikan manusia kepada pokok pangkalnya, fitrahnya yang banî,, , $^{35}$ yang mengharuskan mereka tunduk patuh kepada Allah Swt. ${ }^{36}$

Dalam rangka menjalankan misi ini sudah tentu akan berhadapan dengan musuh yang tidak suka terhadap Islam, setan yang senantiasa menggoda,

${ }^{29}$ Jamaluddin Abi al-Fadl Ibn Mukrim Ibn Mandzur, Lisan Al-Arab (Beirut: Dar Alkutub Al-Ilmiyah, 2003), 708.

${ }^{30}$ Muhammad Fu'ad Abd al-Baqi, Mu'jam Gharib Al-Qur'an; Mustakbrijan Min Shabih AlBukhari (Beirut: Dar Al-Fikr, 2002), 58.

${ }^{31}$ M. Quraish Shihab, Wawasan Al-Qur'an: Tafsir Maudhu'i Atas Pelbagai Persoalan Umat (Bandung: Mizan, 1996), 502.

32 Al-Ashfahaniy, Mu'jam Mufradat Alfaz̧h Al-Qur'an, 99.

33 al-Jurjani, Al-Ta'rifat, 84.

${ }^{34}$ Ali ibn Nafayyi al-Ayani, Tujuan Dan Sasaran Jihad, trans. Abu Fahmi and Ibnu Marjan (Jakarta: Gema Insani Press, 2003), 84.

${ }^{35}$ Didin Hafidhuddin, Membangun Pribadi Qur'ani; Di Bawah Bimbingan Syari'ah Jakarta: Penerbit Harakah, 2002), 95.

${ }^{36}$ Ibid. 
dan hawa nafsu yang cenderung mengganggu perjuangan. Sehingga seluruh kekuatan dan kemampuan yang ada harus dikerahkan untuk menghadapi semuanya harus dilakukan dengan sungguh-sungguh agar tujuan yang hendak dicapai dapat terwujud. Dalam konsekwensinya bisa dilakukan melalui kekuatan fisik (peperangan), dakwah bi lisân dan cara lainnya sesuai dengan situasi dan kondisi yang dihadapi.

Dalam Alquran kata jihad dengan berbagai bentuknya terulang sebanyak 47 kali yang tesebar dalam 19 surat. ${ }^{37}$ Jika diperhatikan ayat-ayat tersebut, pada umumnya tidak menyebutkan objek yang harus dihadapi. Yang secara tegas dinyatakan objeknya hanyalah berjihad menghadapi orang kafir dan munafik. Sebagaimana disebutkan Alquran pada surat al-Tawbah/9:73 dan alTahrîm/66:9, yang kedua ayat ini sama persis redaksinya sebagai berikut:

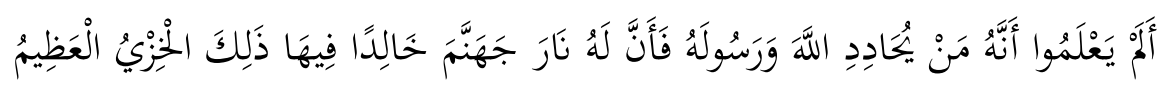

Hai nabi, berjihadlah (melawan) orang-orang kafir dan orang-orang munafik itu, dan bersikap keraslah terhadap mereka. tempat mereka ialah jahannam. dan itu adalah tempat kembali yang seburuk-buruknya.

Ayat ini memerintahkan Nabi Muhammad saw yang berarti juga berlaku atas umatnya untuk berjihad melawan orang-orang kafir dan orang-orang munafik. Berdasarkan dari beberapa riwayat, para ahli tafsir menjelaskan bahwa melakukan jihad terhadap orang-orang kafir adalah memerangi mereka dengan senjata. Sedangkan berjihad terhadap orang-orang munafik adalah melalui lisan yaitu melakukan dialog dengan huijah (argumentasi) dan penjelasan yang kuat untuk mengalahkan mereka. ${ }^{38}$

Sesuai dengan tuntutan ayat tersebut, sikap keras terhadap orang-orang kafir dan munafik yang Nabi saw jalankan itu merupakan suatu siasat yang tinggi yang diatur oleh Allah dan kenyataannya berhasil, karena dengan perlakuan seperti itu banyak orang-orang yang kafir dan munafik bertaubat dan kembali beriman. Tetapi orang-orang yang masih belum sadar karena hanyut dan tenggelam dalam kemunafikan atau kekufuran, tempat mereka adalah neraka jahannam untuk selama-lamanya, yang berarti mereka mendapat tempat paling buruk di akhirat. ${ }^{39}$

37 Abd al-Baqi, Mu'jam Gharib Al-Qur'an, 232-33.

38 Abu Ja'far bin Jarir al-Thabari, Jami' Al-Bayan Fi Ta'wîl Al-Qur'an, 6 (Beirut: Dar alKutub al-Ilmiyyah, 1999), 419-20; Imaduddin Abi al-Fida Isma'il ibn Katsir, Tafsir Al-Qur'an AlAz̧bim, 4 (Kairo: Maktabah al-Shafa, 2004), 105; Abu Muhammad bin Ahmad al Anshari al Qurthubi, Al Jami' Li Abkam Al-Qur'an, 8 (Beirut: Dar al Kutub al Ilmiyah, 1993), 178-79.

${ }_{39}$ Tim Penyusun Depag RI, Al-Qur'an Dan Tafsirnya, 4 (Yogyakarta: Universitas Islam Indonesia, 1991), 189. 
Berdasarkan hal ini, terdapat perbedaan pendapat tentang jihad dan sikap keras terhadap orang-orang munafik itu. Apakah dengan pedang (senjata) seperti yang diriwayatkan oleh Alî ibn Abî Thâlib ra., yang dipilih oleh Ibn Jarîr atas sikap keras itu diterapkan dalam pergaulan dengan mereka dan menyingkap rahasia-rahasia kebusukan mereka untuk diketahui oleh masyarakat umum, seperti yang diriwayatkan oleh Ibn 'Abbâs ra. dan sebagaimana yang terjadi pada masa Rasulullah saw., dimana beliau tidak membunuh orang-orang munafik. ${ }^{40}$

Menurut penulis, keduanya bisa saja berlaku dan harus diterapkan terhadap orang-orang munafik. Tergantung dengan sikap yang diperlihatkan oleh orang-orang munafik itu. Melakukan jihad dengan hujjah (argumentasi) terhadap mereka merupakan tuntunan dan tuntutan Alquran dalam banyak ayat. Namun pada suatu waktu berjihad dengan makna berperang untuk membunuh mereka bisa saja dilakukan ketika sikap mereka benar-benar telah melampaui batas. Dengan kata lain melakukan jihad melalui huijah lebih diutamakan dan didahulukan untuk menghadapi orang-orang munafik. Adapun melakukan jihad dengan berperang membunuh mereka adalah tindakan alternatif akhir atau bahkan menjadi kewajiban yang harus dijalankan apabila syarat-syarat untuk melakukan itu telah terpenuhi.

5. Membangun Kewaspadaan

Strategi lainnya untuk menghadapi orang munafik menurut Alquran adalah dengan senantiasa waspada terhadap mereka. Alquran memberikan peringatan kepada orang-orang mukmin untuk mengambil sikap ini dalam menghadapi mereka. Allah Swt berfirman dalam surat al-Munâfiqûn/63:4

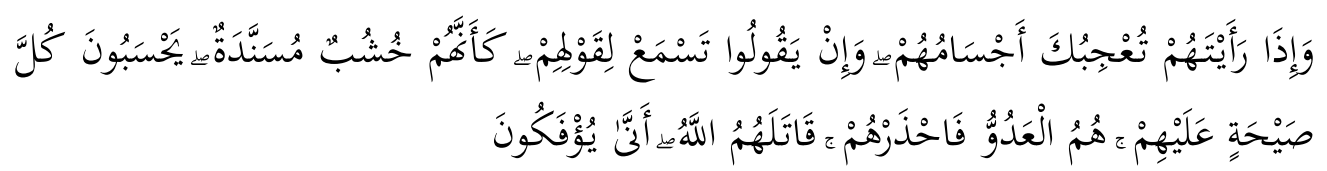

Dan apabila kamu melihat mereka, tubuh-tubuh mereka menjadikan kamu kagum. dan jika mereka berkata kamu mendengarkan perkataan mereka. mereka adalah seakan-akan kayu yang tersandar. Mereka mengira bahwa tiap-tiap teriakan yang keras ditujukan kepada mereka. mereka itulah musuh (yang sebenarnya) maka waspadalah terhadap mereka; semoga Allah membinasakan mereka. bagaimanakah mereka sampai dipalingkan (dari kebenaran)?

Peringatan Allah kepada orang-orang mukmin untuk mewaspadai orangorang munafik pada ayat ini disampaikan setelah sebelumnya menjelaskan

\footnotetext{
${ }^{40}$ Sayyid Quthb, Fi Zhilal Al-Qur'an, 3 (Kairo: Dar al-Syuruq, 1998), 1677.
} 
tentang hakekat yang sebenarnya dibalik kondisi lahiriah orang-orang munafik. Dimana jasad-jasad mereka memang terlihat sangat menakjubkan. Namun mereka bukan orang-orang yang dapat berinteraksi dengan baik. Jika mereka berbicara, lidah-lidah mereka pun fasih sehingga orangpun menaruh perhatian kepadanya karena gaya bahasanya yang sangat tinggi. Namun pembicaraan mereka kosong dari segala makna dan nilai, dari segala perasaan dan segala pikiran. Tidak ada manfaat yang dapat diambil. Secara batin, sebenarnya mereka berada di puncak kegelisahan, dan dalam kondisi kekhawatiran, kengerian, ketakutan, keterkejutan, dan keguncangan yang terus menerus. Kondisi ini digambarkan dalam ayat tersebut dengan perumpamaan seperti kayu yang sangat besar. ${ }^{41}$

Kewaspadaan terhadap orang-orang munafik yang harus dibangun oleh orang-orang mukmin adalah beralasan pada bahaya-bahaya yang dapat ditimbulkan oleh orang-orang munafik. Sementara itu, bahaya orang-orang munafik dapat dilihat dari karakter-karakter buruk mereka. Orang-orang mukmin harus membangun kewaspadaan tidak hanya terhadap sosok orangorang munafik semata, tatapi juga terhadap sifat kemunafikan itu sendiri. Apabia "virus" kemunafikan telah menjangkiti kaum mukmin, bagaimana mungkin mereka akan dapat menghadapi kaum munafik. Oleh karenanya mukmin senantiasa dituntut untuk melakukan introspeksi diri terehadap setiap amal hati dan perbuatannya, apakah padanya ada unsur-unsur nifâq yang harus dijauhi.

Sebagai wujud kewaspadaan terhadap orang munafik, Rasulullah saw, dalam satu riwayat menitipkan kepada Hudzaifah adalah pemegang rahasia Rasulullah saw. Orang-orang munafik yang diberitahukan oleh Rasulullah itu jumlahnya lebih dua belas orang, namun yang dua belas orang dianggap bahaya lebih besar dan bahwa mereka tidak akan bertaubat atas kemunafikan serta mereka akan berujung dengan akibat yang sangat buruk. Mereka yang dua belas ini oleh Nabi dikabarkan tidak akan masuk surga dan mencium baunya. ${ }^{42}$

Itu sebabnya, para sahabat Rasulullah saw, selalu bertanya kepada Hudzaifah tentang apakah mereka termasuk dalam golongan munafik sebagaimana yang diberitahukan oleh Rasulullah saw. Mereka sangat takut dan mewaspadai kemunafikan itu ada pada diri mereka. Di antaranya 'Umar ibn alKhaththâb yang dikenal sebagai orang yang sangat besar kecintaannya kepada

${ }^{41}$ Imaduddin Abi al-Fida Isma'il ibn Katsir, Tafsir Al-Qur'an Al-Azbim, 8 (Kairo: Maktabah al-Shafa, 2004), 81; Sayyid Quthb, Fi Zhilal Al-Qur'an, 6 (Kairo: Dar al-Syuruq, 1998), 3574-75.

${ }^{42}$ Muhammad Musa Nasr, Munafik Menurut Al-Qur'an Dan Al-Sunnah, trans. Nabhani Idris (Jakarta: Darus Sunnah Press, 2004), 96. 
Rasulullah saw. Pasca keislamannya, ia juga datang bertanya kepada Hudzaifah tentang daftar orang-orang munafik, apakah ia termasuk salah satunya. ${ }^{43}$

Pada pergaulan sehari-hari orang-orang mukmin harus senantiasa waspada dalam melakukan hubungan dengan sesamanya, karena kemunafikan itu bisa saja ada dan muncul pada setiap diri seseorang yang kelihatannya sangat bersahaja pada kebaikan, ibadahnya tertib, perilakunya sangat sesuai dengan Islam, hingga tak ada alasan lagi orang untuk tidak mempercayainya. Namun sekali waktu seseorang itu ternyata juga dapat melakukan hal-hal yang di luar persangkaan orang sebelumnya, ia berkhianat dan melakukan perbuatanperbuatan buruk lainnya. Atau sebaliknya, ada seseorang yang dikenal memiliki perilaku yang buruk, sehingga tidak ada alasan untuk dapat mempercayainya. Namun pada sekali waktu, ternyat ia adalah orang yang sangat jujur, tidak seperti yang disangkakan orang terhadapnya.

Alquran menginformasikan bahwa pada dasarnya manusia memiliki dua potensi yang saling berlawanan antara satu dengan yang lainnya. Yaitu potensi yang mengarahkan seseorang untuk melakukan keburukan dan potensi untuk berbuat kebaikan. Sebagaimana firman Allah Swt dalam surat al-Syams; 7-10

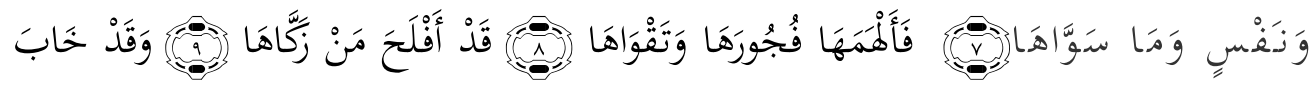

[7] Dan jiwa serta penyempurnaannya (ciptaannya), [8] Maka Allah mengilhamkan kepada jiwa itu (jalan) kefasikan dan ketakwaannya. [9] Sesungguhnya beruntunglah orang yang mensucikan jiwa itu, [10] Dan Sesungguhnya merugilah orang yang mengotorinya.

Berkenaan dengan ini, kewaspadaan yang harus dibangun orang-orang mukmin meliputi seluruh komponen yang ada pada lingkungan pergaulannya. Bahkan terhadap keberadaan dirinya sendiri. Kewaspadaan dimaksud direalisasikan dengan sikap hati-hati dalam mencari teman bergaul, yang bukan berarti senantiasa berprasangka buruk terhadap setiap orang. Kewaspadaan berarti menyadari bahwa setiap orang, bahkan diri sendiri dapat saja berperilaku buruk sebagaimana perilaku orang munafik. Oleh karenanya, segala upaya preventif untuk mengatasi agar hal itu tidak muncul harus dilakukan.

${ }^{43}$ Ibid. 


\section{Memperbanyak Doa}

Menurut Alquran, kata doa mengandung arti memohon, mengharap, meminta, memanggil, menyeru, memuji, mengabdi, menyembah atau beribadah. ${ }^{44}$ Kata doa dengan arti yang bermacam-macam ini terdapat dalam 203 ayat. ${ }^{45}$ Kata ini telah menjadi buku dalam bahasa Indonesia yang berarti permohonan (harapan, permintaan, pujian) kepada Tuhan. ${ }^{46}$

Secara istilah, doa adalah memohon sesuatu dari Allah Swt dengan harapan agar Allah Swt mengabulkannya. ${ }^{47}$ Atau ada yang mengartikannya, meminta sesuatu sesuai dengan hajatnya atau memohon perlindungan kepada Allah Swt. terhadap bencana, bala, malapetaka, dan sebagainya. Dengan merendahkan diri dan tunduk kepada-Nya; dan ia merupakan bagian dari ibadah. ${ }^{48}$

Penjelasan lain, mengartikan doa adalah suatu aktivitas ruhaniah yang mengandung permohonan kepada Allah Swt melalui lisan atau hati, dengan menggunakan kalimat-kalimat atau pernyataan-pernyataan khusus sebagaimana yang tertulis dalam Alquran, al-Sunnah ataupun keteladanan para sahabat Rasulullah saw dan orang-orang saleh. Dengan penuh harapan agar doa-doa yang dimohon itu akan segera dikabukan. ${ }^{49}$

Dalam pembahasan ini, doa yang dimaksud adalah memohon kepada Allah Swt melalui lisan dan hati, dengan mengucapkan kalimat-kalimat dan memenuhi adab-adab sebagaimana yang diajarkan dan terdapat dalam ayat-ayat Alquran, khususnya yang berhubungan dengan permohonan mengharapkan pertolongan Allah Swt agar menang dalam menghadapi orang-orang kafir.

Alquran mengajarkan bahwa dalam menghadapi musuh, strategi yang harus dilakukan salah satunya adalah dengan memperbanyak doa. Termasuk dalam hal ini menhadapi orang-orang munafik sebagai musuh tersembunyi yang sangat berbahaya. Allah berfirman dalam surat al-Anfâl/8:45

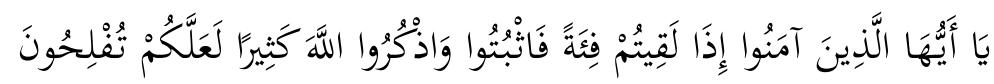

\footnotetext{
${ }^{44}$ Rahmat Taufiq Hidayat, Khazanah Istilah Al-Qur'an (Bandung: Mizan, 1993), 41.

${ }^{45}$ Abd al-Baqi, Mu'jam Gharib Al-Qur'an, 326-30.

${ }^{46}$ Departemen Pendidikan dan Kebudayaan, Kamus Besar Bahasa Indonesia, 239.

${ }^{47}$ Hidayat, Khazanah Istilah Al-Qur'an, 41.

${ }^{48}$ Shadiq and Shalahuddin Chaery, Kamus Istilah Agama (Jakarta: CV. Sienttarama,

${ }^{49}$ Hamdani Bkran Adz-Dzakiey, Prophetic Intelligence: Kecerdasan Kenabian Mnumbubkan Potensi Hakiki Insani Melalui Pengembangan Kesehatan Rubani (Yogyakarta: Islamika, 2005), 451.
} 1983), 82. 
Hai orang-orang yang beriman. apabila kamu memerangi pasukan (musuh), berteguh hatilah dan sebutlah (nama) Allah sebanyak-banyaknya agar kamu beruntung.

Diantara makna menyebut nama Allah sebanyak-banyaknya pada ayat ini adalah memperbanyak doa. ${ }^{50}$ Dengan doa, orang-orang mukmin mengharapkan datangnya pertolongan Allah Swt. Mukmin menyadari bahwa sebesar apapun kekuatan yang dimilikinya belum pasti dapat mengalahkan musuh yang lemah atau menyelesaikan persoalan yang kecil sekalipun, tanpa izin dan ridha Allah Swt. Sebaliknya, sekecil apapun kekuatan yang dimiliki, bila Allah ridha atasnya, dipastikan akan dapat mengalahkan musuh dan menyelesaikan segala persoalan yang besar. Karenanya, doa merupakan upaya untuk mendapatkan keridhaan Allah atas usaha yang dilakukan. Dengan itu pertolongan Allah diharapkan dan bahkan ia merupakan kebutuhan mutlak sekaligus keniscayaan. Hal ini penting diyakini oleh setiap mukmin dalam aktivitas usaha yang dilakukan pada kehidupan ini.

Sejarah kehidupan para Nabi dan orang-orang saleh terdahulu telah membuktikan hal itu. Sebagai contoh, ketika terjadi perang Badar, kaum muslimin yang jumlahnya sedikit dapat mengatasi kaum musyrikin yang jumlahnya empat kali lebih banyak. Itu terjadi semata-mata dengan pertolongan Allah Swt. ${ }^{51}$ Peristiwa itu diabadikan Allah melalui firman-Nya dalam Alquran dalam surat ali 'imrân/3:123

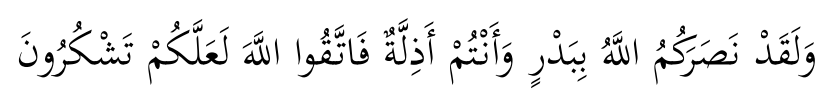

Sungguh Allah telah menolong kamu dalam peperangan Badar, padahal kamu adalah (ketika itu) orang-orang yang lemah. Karena itu bertakwalah kepada Allah, supaya kamu mensyukuri-Nya.

Pertolongan Allah Swt itu diberikan kepada orang-orang mukmin adalah buah dari usaha yang mereka lakukan baik melalui aktivitas lahiriah dan batiniah yang dilakukan dengan sungguh-sungguh dan secara terus menerus (mujâhadah dan istimrariyyah). Yaitu dengan membuktikan kepada Allah Swt akan keimanan yang kuat kepada-Nya disertai dengan keyakinan bahwa ajaran-Nya mampu menjawab berbagai persoalan yang mereka hadapi dan adanya keseriusan kaum mukmin untuk mengamalkan aturan Islam dalam tataran hidup

50 Tim Penyusun Yayasan Penyelenggara Penerjemah/Penafsir Al-Qur'an Departemen Agama RI Al-Qur'an dan Terjemah, Al-Qur'an Dan Terjemah (Semarang: PT. Kuusmudasmoro Grafindo, 1994), 268.

${ }^{51}$ Hafidhuddin, Membangun Pribadi Qur'ani, 124. 
pribadi maupun berbangsa dan bernegara. ${ }^{52}$ Dengan ini orang-orang mukmin mengundang pertolongan Allah. Dan Allah pasti akan memenuhi undangan itu, karena orang-orang mukmin telah lebih dahulu membuktikan komitmennya untuk berpihak hanya kepada-Nya dalam segala urusan hidupnya.

\section{Kesimpulan}

Strategi menghadapi orang munafik menurut Alquran sebagaimana telah diuraikan, dapat dikelompokkan menjadi tiga macam aspek, pertama, strategi yang berkaitan dengan internal kaum mukmin sendiri, yang meliputi: memperkokoh loyalitas sesama mereka, menolak orang munafik sebagai teman dekat/kepercayaan dan pemimpin. Kedua, strategi yang berkaitan dengan eksternal kaum mukmin, yaitu ketika berhadapan langsung dengan orang munafik. Ini meliputi: melakukan jihad terhadap orang-orang munafik melalui dialog dengan mengemukakan hujjah (argument) untuk melemahkan mereka, dan puncak dari jihad yang sebenarnya itu ialah memerengi mereka dengan senjata, menangkap, membawa bahkan membunuh mereka, ketika perilaku sudah melewati batas toleransi yang telah digariskan oleh Allah Swt sebagaimana diajarkan dalam Alquran. Ketiga, strategi yang berkaitan dengan aspek keduanya sekaligus (internal dan eksternal). Ini meliputi: kewaspadaan yang harus dibangun dan selalu ditegakkan oleh orang mukmin baik secara individu maupun kelompok masyarakat, pada setiap waktu dan tempat dalam pergaulannya, baik ketika bersama orang-orang mukmin sendiri, apalagi ketika berada di tengah-tengah orang-orang munafik kemudian memperbanyak doa, mengharap pertolongan dan keridoan Allah dalam usaha menjauhi kemunafikan dan menghadapi orang-orang munafik tersebut.

\section{Bibliografi}

Abd al-Baqi, Muhammad Fu'ad. Al-Mu'jam Al-Mufahras Li Alfað̧h Alquran AlKarim. Beirut: Dar Al-Fikr, 1417.

. Mu’jam Gharib Alquran; Mustakhrijan Min Shahih Al-Bukhari. Beirut: Dar Al-Fikr, 2002.

Adz-Dzakiey, Hamdani Bkran. Prophetic Intelligence: Kecerdasan Kenabian Mnumbuhkan Potensi Hakiki Insani Melalui Pengembangan Kesehatan Ruhani. Yogyakarta: Islamika, 2005.

Al-Ashfahaniy, Ar-Raghib. Mu'jam Mufradat Alfað̧ Alquran. Beirut: Dar Alkutub Al-Ilmiyah, 2008.

${ }^{52}$ Ibid., 139-40. 
Al-Buraikhan, Ibrahin ibn Muhammad bin Abdullah. Pengantar Studi Aqidah Islam. Translated by Muhammad Anis Matta. Jakarta: Robbani Press, 1998.

Al-Nadur, Abdullah Abbas. Qamus Alfað̧ Alquran. Beirut: Dar Al-Fikr, 1986.

Al-Shabuni, Muhammad 'Ali. Cabaya Alquran; Tafsir Tematik Surat Al-Baqarah-AlAn'am,1. Translated by Kathur Sukardi. Jakarta: Pustaka al-Kautsar, 2000.

Arief, Armai. Pengantar Ilmu Dan Metodologi Pendidikan Islam. Jakarta: Ciputat Press, 2002.

Ayani, Ali ibn Nafayyi al-. Tujuan Dan Sasaran Jihad. Translated by Abu Fahmi and Ibnu Marjan. Jakarta: Gema Insani Press, 2003.

Bayanuni, Ahmad 'Izz al-Din al-. Al-Kufr Wa Al-Mukaffirat. Halb: Maktabah alHuda, 1979.

Cawidu, Harifuddin. Konsep Kufr Dalam Al Qur'an. Jakarta: Bulan Bintang, 1991.

Depag RI, Tim Penyusun. Alquran Dan Tafsirnya, 4. Yogyakarta: Universitas Islam Indonesia, 1991.

Departemen Agama RI, Tim Penyusun Yayasan Penyelenggara Penerjemah/Penafsir Alquran, Alquran dan Terjemah. Alquran Dan Terjemah. Semarang: PT. Kuusmudasmoro Grafindo, 1994.

Departemen Pendidikan dan Kebudayaan, Tim Penyusun Kamus Pusat Pembinaan dan Pengembangan Bahasa. Kamus Besar Bahasa Indonesia. 2nd ed. Jakarta: Balai Pustaka, 1995.

Hafidhuddin, Didin. Membangun Pribadi Qur'ani; Di Bawah Bimbingan Syari'ah. Jakarta: Penerbit Harakah, 2002.

Hawwa, Sa'id. Mensucikan Jiwa; Konsep Tazkiyatun Nafs Terpadu. Translated by Aunur Rafiq Shaleh. Jakarta: Rabbani Press, 1998.

Hidayat, Rahmat Taufiq. Khazanah Istilah Alquran. Bandung: Mizan, 1993.

Ibn Mandzur, Jamaluddin Abi al-Fadl Ibn Mukrim. Lisan Al-Arab. Beirut: Dar Al-kutub Al-Ilmiyah, 2003.

Jauziyyah, Ibn al-Qayyim al-. Madarijus Salikin: Pendakian Menuju Ilahi. Translated by Kathur Suhardi. Jakarta: Pustaka al-Kautsar, 1998.

Jurjani, Ali ibn Muhammad ibn 'Ali al-Husaini al-. Al-Ta'rifat. Beirut: Dar al-Kutub al-Ilmiyyah, 2003.

Katsir, Imaduddin Abi al-Fida Isma'il ibn. Tafsir Alquran Al-Azhim, 2. Kairo: Maktabah al-Shafa, 2004.

—. Tafsir Alquran Al-Azhim, 3. Kairo: Maktabah al-Shafa, 2004. 
- Tafsir Alquran Al-Azhim, 4. Kairo: Maktabah al-Shafa, 2004.

—. Tafsir Alquran Al-Azhim, 8. Kairo: Maktabah al-Shafa, 2004.

Khalid, Amru. Pesona Alquran Dalam Matarantai Surah Dan Ayat. Translated by Ahmad Fadhil. Jakarta: Sahara Publishers, 2005.

Naisaburi, Abi al-Hasan 'Ali ibn Ahmad al-Wahidi al-. Asbab Al-Nuzul. Beirut: Dar Al-Fikr, 1994.

Nasr, Muhammad Musa. Munafik Menurut Alquran Dan Al-Sunnah. Translated by Nabhani Idris. Jakarta: Darus Sunnah Press, 2004.

Qurthubi, Abu Muhammad bin Ahmad al Anshari al. Al Jami' Li Ahkam Alquran, 6. Beirut: Dar al Kutub al Ilmiyah, 1993.

—. Al Jami' Li Ahkam Alquran, 8. Beirut: Dar al Kutub al Ilmiyah, 1993.

Quthb, Sayyid. Fi Zhilal Alquran, 3. Kairo: Dar al-Syuruq, 1998.

—. Fi Zhilal Alquran, 6. Kairo: Dar al-Syuruq, 1998.

Shadiq, and Shalahuddin Chaery. Kamus Istilah Agama. Jakarta: CV. Sienttarama, 1983.

Shihab, M. Quraish. Tafsir Al-Misbah, 2. Jakarta: Lentera Hati, 2002.

- Wawasan Alquran: Tafsir Maudhu'i Atas Pelbagai Persoalan Umat. Bandung: Mizan, 1996.

Thabari, Abu Ja'far bin Jarir al-. Jami' Al-Bayan Fi Ta'wîl Alquran, 3. Beirut: Dar al-Kutub al-Ilmiyyah, 1999.

. Jami' Al-Bayan Fi Ta'wîl Alquran, 6. Beirut: Dar al-Kutub alIlmiyyah, 1999.

Thabathaba'i, Muhammad Husayn. al-Mizan fi Tafsir al-Qur'an, 19. Tegeran: Mu'assasat Dar al-Kutub al-Islamiyyah, 1396.

Zahrah, Abu. Dakwah Islamiyah. Translated by Ahmad Subandi and Ahmad Sumpeno. Bandung: PT. Remaja Rosdakarya, 1994. 